\title{
Subsurface River Flow Study in Oksibil of Pegunungan Bintang District by Very Low Frequency Electromagnetic Method
}

\author{
Sismanto $^{1, a}$, Salahuddin Husein ${ }^{2}$ and Eddy Hartantyo ${ }^{1}$ \\ ${ }^{1}$ Geophysics Laboratory, Physics Dept. FMIPA, UGM, Yogyakarta. \\ ${ }^{2}$ Geological Engineering, UGM, Yogyakarta. \\ ae-mail: sismanto@ugm.ac.id
}

\begin{abstract}
Pegunungan Bintang district with the capital Oksibil, almost all of its territory is mountains of karst, especially in the west area, people living in the mountain slopes and small valleys in small groups, scattered and isolated. Karst areas, in general, has a lot of subsurface cavities at a developed stage to form subsurface rivers. Therefore, as the capital of the District Oksibil need to know the local subsurface conditions, how much growth cavities that exist in Oksibil. So that the study was carried out by very low frequency electromagnetic (VLF) method. Based on the field measurement and VLF data analysis, the interpretation and the dolina correlation, the Oksibil area is still safe, by considering that there is no indication of dolina or subsurface river that continued relatively horizontal, and the subsurface doline at relatively quite deep ( $>\mathbf{4 0}$ meters).
\end{abstract}

Keywords : Karst, Oksibil, VLF

\section{INTRODUCTION}

Pegunungan Bintang district, almost all of its territory is mountainous areas, especially in the western part, people living in the steep mountain slopes and small valleys in small groups, scattered and isolated ; lowlands only in the north and south with the accessibility of the region is very low, making it difficult to reach so that all services can only be done by air transport. However, the Pengunungan Bintang District has a lot of potential in the form of natural resources, both renewable and non-renewable, but Oksibil district is dominated by Limestone Yawee by Dow et al. [1] are relatively homogeneous and can not be used optimally, for community empowerment. This is the difficulties and the limitations faced by the local government [2].

Karst areas, in general have many cavities that formed at subsurface on advanced stage to form tunnels or subsurface streams [3]. Therefore, as the capital of the District Oksibil need to know the local subsurface conditions, i.e. how far the growth of cavities or subsurface river. One of the non-destructive geophysical methods for imaging the subsurface river is low frequency electromagnetic method (VLF). The subsurface conditions is related to the presence of cavities in subsurface interconnected, while at the surface will be developed some physical facilities and others settlement building and district offices. So, given the limited surface condition that can be developed, being a good construction site is quite difficult in Pengunungan Bintang.

Mapping the subsurface condition associated with the presence of cavities under the ground, for the sake of securing the future development planning on the surface that it needs supports the analysis of regional development policies in particular Oksibil district, Pegunungan Bintang, Papua province.

Geophysical method uses principles of physics to study the earth. Almost all geophysical methods have been used to explore the existence of natural resources for the benefit of humans, such as oil and gas, mining materials, ground water, sources of geothermal energy and others. Geophysical method is generally performed in order to determine the existence of anomalous rock, position of the system, dimension and physical properties of the anomaly [4].

Rivers or subsurface cavity formed many branches of the flow, along with the intensive formation of holes that are interconnected (permeable) on limestone lithology is the target of this survey by using of VLF electromagnetic method. VLF method can be used to map the presence of rivers or subsurface cavity, by modifying the coefficients Karous-Hljet filter and topography correction that adapted to local conditions of Oksibil in Papua.

\section{THEORY AND METHODOLOGY}

The VLF method is an inductive exploration method that measures variation in EM field components related to the electrical structure of the subsurface. The method utilizes source of EM signals propagated by a remote transmitter (vertical electric dipole) within the frequency range of 15 to $30 \mathrm{kHz}$. Transformation filter that transforms the measured $\mathrm{Hz} / \mathrm{Hy}$ (known as tipper in MT-related 
subjects) into apparent resistivity profiles was first introduced with the assumption that the spatial derivatives of the horizontal magnetic field can be neglected along the profile [5].

The laws that govern the electromagnetic wave propagation are the Maxwell equations. Two of them are, Faraday's law and Ampere's law

$$
\begin{array}{r}
\bar{\nabla} \times \bar{E}=-\frac{\partial B}{\partial t} \\
\bar{\nabla} \times \bar{H}=J+\frac{\partial D}{\partial t}
\end{array}
$$

where $J$ is the current density $\left(\mathrm{A} / \mathrm{m}^{2}\right), E$ is the electric field $(\mathrm{V} / \mathrm{m}), B$ is the magnetic induction field $\left(\mathrm{Wb} / \mathrm{m}^{2}\right), D$ is the dielectric displacement $(\mathrm{C} / \mathrm{m})$, and $H$ is the magnetic field $(\mathrm{A} / \mathrm{m})$. The simple representations of equation (1) and (2) for electromagnetic wave propagation in homogenous and isotropic medium are,

$$
\begin{gathered}
\nabla^{2} E=i \omega \mu \sigma E-\omega^{2} \varepsilon \mu E \\
\nabla^{2} H=i \omega \mu \sigma H^{2}-\omega^{2} \varepsilon \mu H
\end{gathered}
$$

where is the permeability $(\mathrm{H} / \mathrm{m})$, is the capacity $(\mathrm{F} / \mathrm{m})$, is the conductivity $(\mathrm{mho} / \mathrm{m})$, and $\omega=2 \pi f$ is the angular frequency. The propagation of electromagnetic wave will induce electric charge on conductor. The conductor create a secondary field and interfere with the primary field, consequently the resultant field will polarize in elliptic shape. According to Smith and Ward [6] on the condition that the horizontal magnetic field is $H_{x} \exp (i x)$ and the vertical magnetic field is $H_{z} \exp (i z)$, the magnitude of the tilt angel (see Fig. 1) is

$$
\tan (2 \theta)=\frac{2\left(\mathbf{H}_{z} / \mathbf{H}_{x}\right) \cos \Delta \phi}{1-\left(\mathbf{H}_{z} / \mathbf{H}_{x}\right)^{2}}
$$

where $\Delta \phi=\phi_{z}-\phi_{x}$, and the ellipticity value is

$$
\begin{aligned}
\varepsilon & =\frac{\mathbf{H}_{z} e^{i \Delta \phi} \cos \theta-\mathbf{H}_{x} \sin \theta}{\left|\mathbf{H}_{z} e^{i \Delta \phi} \sin \theta+\mathbf{H}_{x} \cos \theta\right|^{2}} \\
& =\frac{\left(\mathbf{H}_{z} / \mathbf{H}_{x}\right) \sin \Delta \phi}{\left|\mathbf{H}_{z} e^{i \Delta \phi} \sin \theta+\mathbf{H}_{x} \cos \theta\right|^{2}}
\end{aligned}
$$

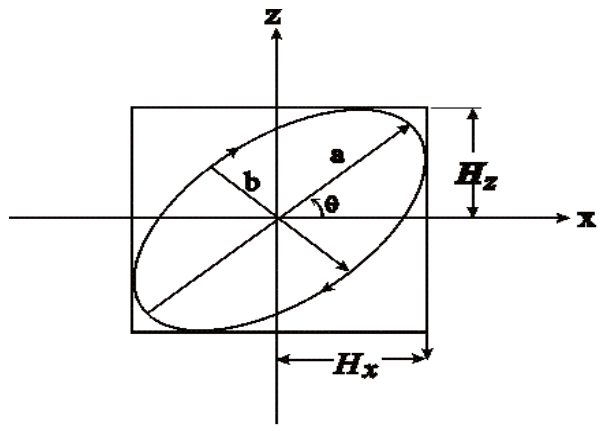

Figure 1. Ellipse polarization parameters.

The tangent of the tilt angle and ellipticity are good approximations to the real and quadrature components of the tipper, respectively. They are often expressed in percentage as the real $(\tan \alpha \times 100 \%)$ and the imaginary $(\varepsilon \times 100 \%)$ anomalies which will be the focus of our study. In the VLF data acquisition we use T-IRIS instrument [7]. The tilt angle and ellipse value are recorded and filtered by moving average for smoothing and then by linier filter of Karous and Hjelt [8] such as;

$$
\frac{\Delta z}{2 \pi} I_{a}\left(\frac{\Delta x}{2}\right)=0.115 H_{-1}-0.1383 H_{0}+0.1383 H_{1}-0.115 H_{2}
$$

where $\Delta z$ is the depth $(\mathrm{m}), I_{\alpha}$ is the current density equivalent $(\%), \Delta x$ is the space $(\mathrm{m})$, and His the tilt angle (\%). The result of tilt angle data filtering by means of equation (7) for each depth shows a pseudodepthsection of the current density equivalent. The ordinate is the measurement points, and the absis is the depth.

\section{THEORY AND METHODOLOGY}

\section{Geological Setting}

As mentioned above, in geomorphology of Oksibil District are found some caves in the valley between the Mount Uraing and the Mount Oktumbaungke, whereas dolina or hole in the surface can occur as a result of two main processes, i.e. dissolution and debris often found in several places on the surface. The result of the dissolution process goes quickly so it remains as a form of depression. In the second type, dolina occurs when the dissolution process takes place under the surface so intensive that cave that formed a channel becomes very wide and is unable to sustain the load of the roof. When the roof of the cave collapsed, it will form a hole as characterized by a relatively steep valley and met many limestone boulders at its base. One additional requirement for the landscape of karst formation is the process of removal that is not too fast and relatively flat of the topography. So for this area where 
tectonic uplift runs quite fast and has great topography with relief, the landscape of karst not be formed evenly. The landscape of District Oksibil karst only found in areas that are relatively flat in the southern and central characterized by dolina. The process of rapid tectonic uplift caused karst landscapes evolve only limited also cannot reach mature stage, It is characterized by widespread due doline karst valleys are mutually joined to one another.

From the geological survey that was conducted in Oksibil District, obtained that there are three types of lithological units at the surface, i.e. a layered limestone unit, a limestone breccia unit, and clay - gravel unit. The third unit spread to the southwest - southeast direction following the direction of the trend of regional structures. Layered limestone unit is distributed at the south through western Oksibil District, has a characteristic dark gray and well -coated with a thickness ranging from 10 to $40 \mathrm{~cm}$ and is composed of fragments of fossil micro-sized debris to the macro. Besides lifting Oksibil District area of shallow seabed up to an altitude of $\sim 1000 \mathrm{~m}$ at this time, orogenesa Melanesia processes also produce changes in the position of rocks, cracks and fractures. From field observations, the general slope of layered limestone units relative to the north - northeast. This is consistent with the existence of the concept of factoring fault system to the south of the lift Pengunungan Bintang which will tilt towards the north. The force was compressive tectonic north - south trending relative also reflected in the presence or fissure vein systems containing minerals relative trending north - south. Aside from forming cracks that are extensional due to north-south trending tectonic compressive force trending north - south, the same style is also capable of forming cracks trending shear zones are northeast-southwest and northwest- southeast. The crack pattern observed with both shear zones in the drainage pattern of the flow through karst areas, because cracks often found in limestone, allow fluid to flow surface water to dissolve the rocks below the surface, breaking down the lid, and form a karst topography.

\section{VLF Measurements}

NWC-Australia transmitter station $(19.8 \mathrm{kHz})$ was used for the survey in Oksibil. The lines survey was made to the surface that can be reach. We measured the position by using handy Garmin GPS CX-2500 by spacing $10 \mathrm{~m}$. Tilt angel was measured by T-IRIS VLF instrument in tilt mode. Tilt angel is a vertical magnetic field intensity ratio to horizontal magnetic field intensity which is expressed in percentage. The greater tilt angle, the more conductive the source of anomalous.

The results of the measurement and processing of VLF electromagnetic field is presented in Fig. 2a to $2 \mathrm{~h}$. The color bar toward the red areas shows levels below of the surface wetness. Getting hot (red) an area, shows the level of presence of fluid (water) is getting higher. While the relatively cool colors (blue and white) indicates that the area is relatively dry limestone and more compact area.

Fig. 2a shows the distribution of current density value equivalent at a depth of $20 \mathrm{~m}$ from the ground. It mostly have a moderate degree of wetness (colored blue) and relatively dry in some areas. At a depth of $20 \mathrm{~m}$, there are indications that the wet area under the three small Doline in the west of SMK and SMA Oksibil (Indication A). There is also an indication of wet areas in the northern region of Posyandu lead to the parliament building (DPRD), just below the wide doline (indication B). Indications A and B become increasingly apparent at a depth of $40 \mathrm{~m}$ from surface (Fig. 2b ), a local indication of the level of wetness appear higher until it reaches a yellowish green color. Similarly, the indication $\mathrm{B}$, visible wetness levels also increasing, but not as high as indication A.

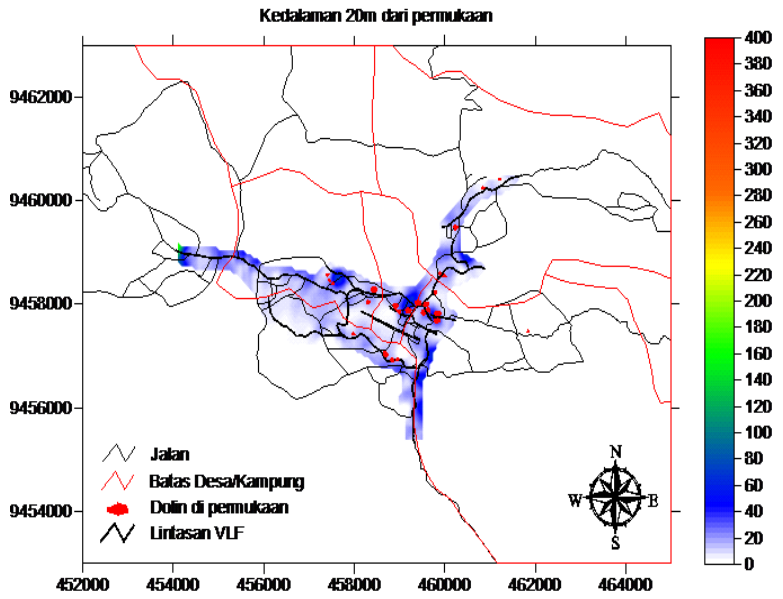

Figure 2a. Current density equivalent distribution on Oksibil at $20 \mathrm{~m}$ in depth.

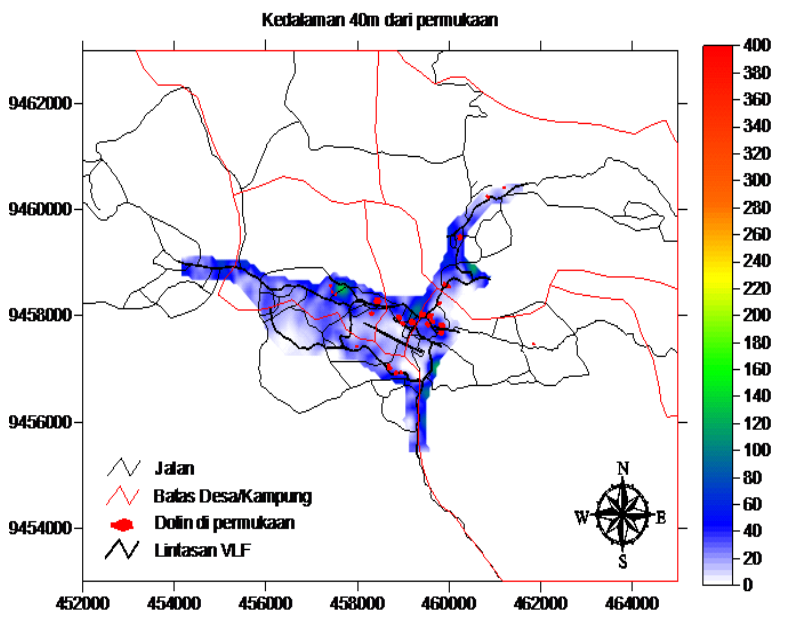

Figure $2 b$. Current density equivalent distribution on Oksibil at $40 \mathrm{~m}$ in depth. 


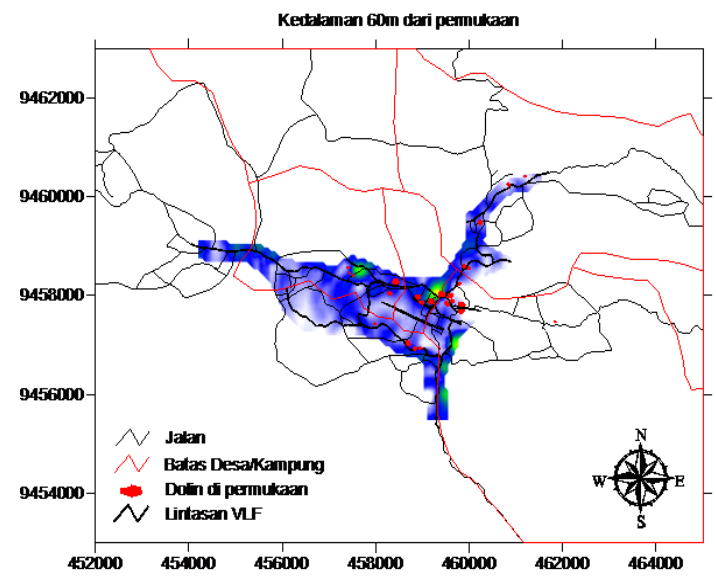

Figure 2c. Current density equivalent distribution on Oksibil at $60 \mathrm{~m}$ in depth.
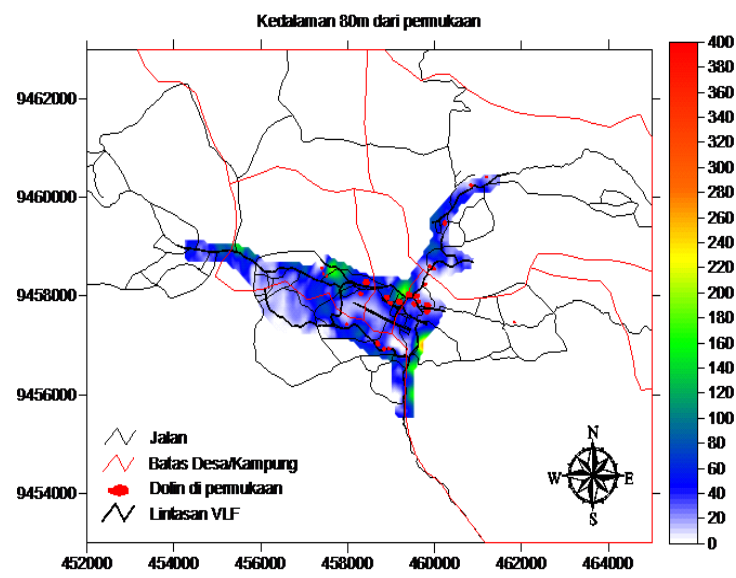

Figure 2d. Current density equivalent distribution on Oksibil at $80 \mathrm{~m}$ in depth.

A doline that is located on the west of Oksibil market, at a depth of $40 \mathrm{~m}$ also indicate as a wet areas (indication C), but it is still low level. Indications A and B are increasingly seen to have a high enough degree of wetness of the incision equivalent current density at a depth of $60 \mathrm{~m}$ (Fig. 2c) and 80m (Fig. 2d) of the surface. However, there is a tendency indication $\mathrm{C}$ increasingly dry.

At deeper depths, the depth of $100 \mathrm{~m}$ (Fig. 2e), indicative of a more wetness, while $\mathrm{B}$ is getting lost indication. Indications $\mathrm{C}$ increasingly appear approaching Oksibil market position. A growing indications at a depth of $120 \mathrm{~m}$ (Fig. 2f), while also increasing indications C, especially in the southeast Doline (around Oksibil market). At a depth of $140 \mathrm{~m}$, is no longer indication of a high wetness, but the level of wetness slightly shifted to the south. Indications B was headed toward a solid dry zone, whereas $C$ relative indication decreasing. At considerable depth in all indications (A, B and C) become weaker, but there are areas that have a relatively increasing level of wetness in the southern parliament building Oksibil.

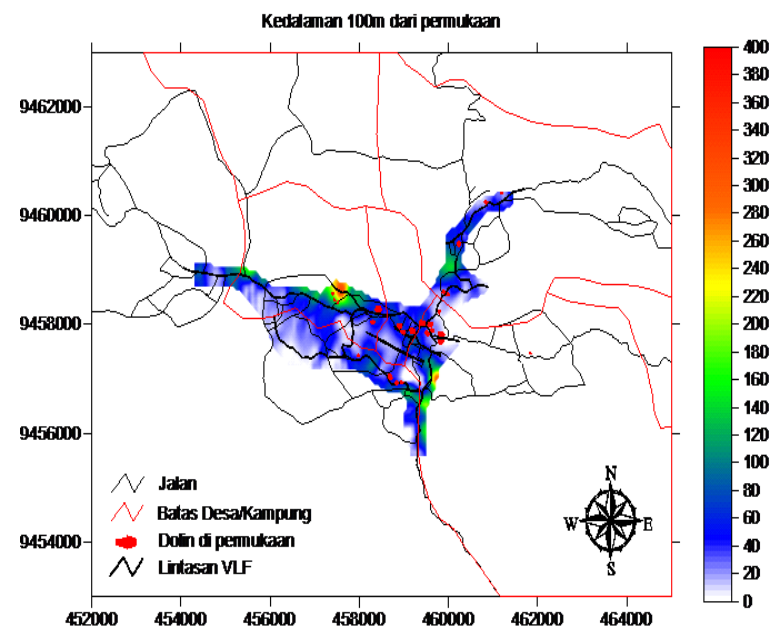

Figure 2e. Current density equivalent distribution on Oksibil at $100 \mathrm{~m}$ in depth.

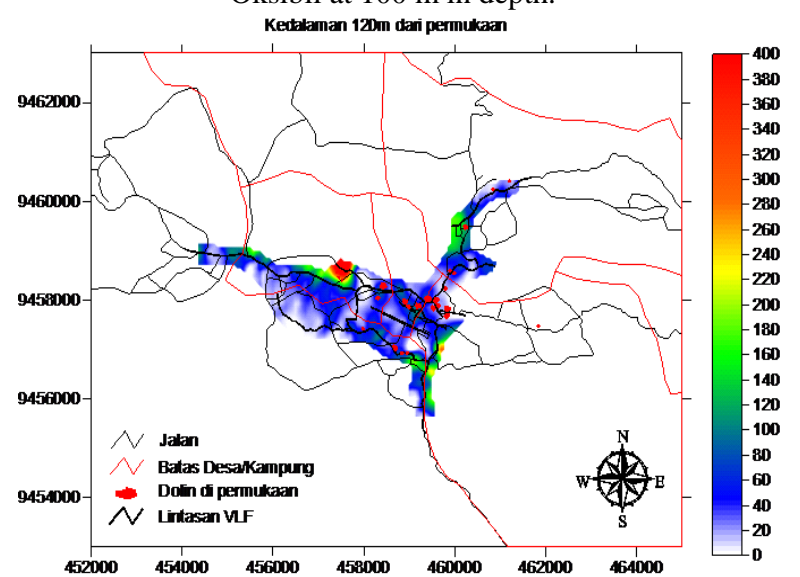

Figure 2f. Current density equivalent distribution on Oksibil at $120 \mathrm{~m}$ in depth.

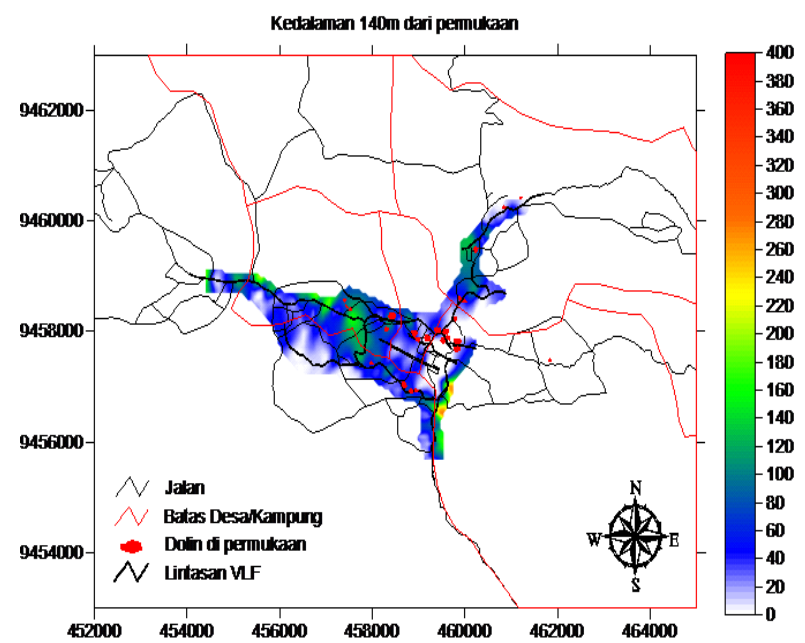

Figure $2 \mathrm{~g}$. Current density equivalent distributionon Oksibil at $140 \mathrm{~m}$ in depth. 


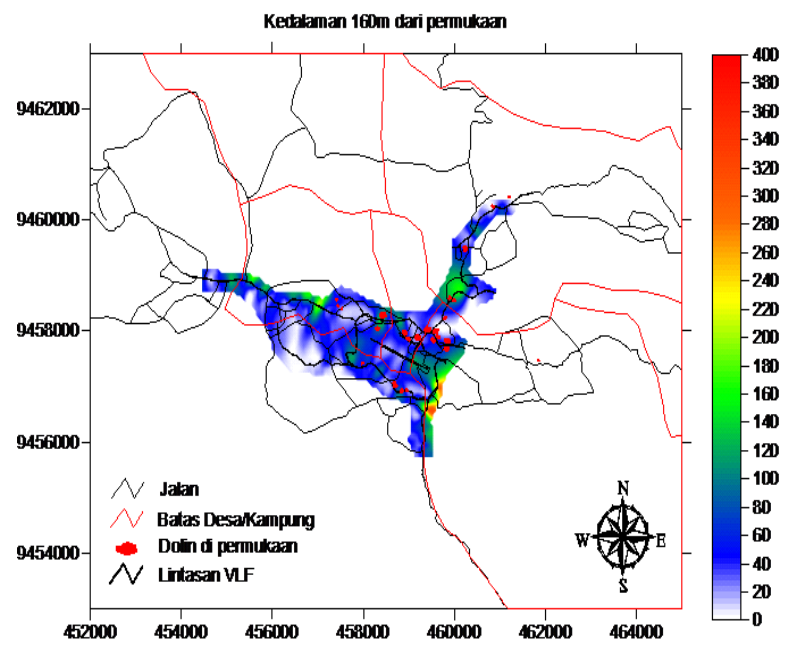

Figure 2h. Current density equivalent distribution on Oksibil at $160 \mathrm{~m}$ in depth.

Based on the analysis of the depth and connection dolina indication, the Oksibil area is still safe, by considering there is no indication doline relatively horizontal and continuous. The subsurface river is an interconnected of dolines at deep enough (over 40 meters) position.

\section{CONCLUSIONS}

1.As the consequence of the process of dissolution and erosion in the Karst landform typical Oksibil is a form of depression known as dolina and positive form of a residual dissolution conical hills or towers. The water is capable of dissolving rock apart, forming a cave system which can also precipitate the dissolved material to form a cave ornaments such as stalactites and stalagmites

2. Oksibil region is still safe, since there is no horizontal and continuous doline relatively. The subsurface river is an interconnected of dolines at more than 40 meters in depth.

3. There are some dolines below the subsurface that is not visible on the surface, so that, this area is not for permanent facilities building.

\section{REFERENCES}

[1] D. B. Dow, G. P. Robinson, U. Hartono, dan N. Ratman, "Peta Geologi Irian Jaya, Indonesia", Lembar 2, Pusat Penelitian dan Pengembangan Geologi, Bandung, 1986.

[2] W .L. Wenda, "Pendayagunaan Potensi Daerah Dalam Rangka Pemberdayaan Masyarakat Di Kabupaten Pegunungan Bintang”. Disampaikan dalam Seminar Percepatan Pembangunan di Tanah Papua. Tgl. 19 Juni 2008, di Jayapura.

[3] O. Bonacci, "Karst Hydrology, Springer Series in Physical Environment",. Springer Verlag, Berlin, 1987.

[4] Sismanto, "Subsurface River Mapping in Bribin Area,
Gunungkidul,Yogyakarta by Using VLF Electromagnetic Method". International Conference on Mathematical and Natural Science ICMNS 2006, November 29-30, 2006, ITB, Bandung.

[5] W. M. Telford, L. P. Geldart, R. E. Sheriff, and D. A. Keys, "Applied Geophysics". Cambridge University Press, 1990

[6] B. D Smith, and S. H. Ward, "On The Computation of Polarization Ellipse Parameters", Geophysics, vol. 39,pp. 867-869, 1974.

[7] Iris, T-VLF Operating Manual, rel 1.0, Iris Instruments,1993

[8] M. Karous,., and S.E. Hjelt, " Linear filtering of VLF DipAngle Mesurement”, Geoph. Prosp., vol. 31, pp. 782-792, 1983. 